\title{
PHYSICO-CHEMICAL PARAMETERS ASSESSTMENT OF CHILAR DAM WATER IN DIFFERENT SITES OF SHAJAPUR TOWN, M.P., INDIA
}

Bodane Arun Kumar *1

${ }^{* 1}$ Department of Chemistry, B.S.N. Govt. P.G. College, Shajapur- 465001, M.P. INDIA

*Correspondence Author: bodane2009@ gmail.com

Abstract:

The present investigation reveals the quality of Dam water for public consumption to determine the Dam water of Shajapur town. Physico-chemical parameters of Dam water were monitored during the study period. The parameters investigated were pH, TDS, Alkalinity, Total Hardness, Chlorides, Magnesium, Fluoride, Nitrates, Dissolve Oxygen and COD. Results obtained from the study revealed that quality of Dam water during study season is well within the permissible limit and the Dam water is safe for drinking or fit for human consumption.

Keywords:

Dam water, Physico-chemical parameters, Drinking water, human consumption, Shajapur town.

Cite This Article: Bodane Arun Kumar, "Physico-Chemical Parameters Assesstment of Chilar Dam Water in Different Sites of Shajapur Town, M.P., INDIA." International Journal of Research-Granthaalayah, Vol. 3, No. 3(2015): 62-69.

\section{INTRODUCTION}

Water in its pure form occurs rarely in nature. Comprising over $70 \%$ of the Earth's surface, water is the most precious natural resource on our planet ${ }^{1}$. Very small amount of water i.e. less than $1 \%$ is fit for human consumption which signifies the importance of this essential commodity on the earth. The most widely spread danger associated with drinking water is the direct or indirect contamination by human and animal feacal matter, chemical, municipal, domestic and industrial liquid discharge etc. Availability of clean water is going to be the greatest constraint for human health. Keeping this into consideration an attempt was made to evaluate the Physicochemical Characteristics of Dam water of the town to determine whether the water is fit for human consumption or not. Water is a basic and primary need of all vital processes and it is now well established that the life first arose in aquatic environment. The population of Shajapur Census 2011 is 1512353 and people depending upon this Dam for their domestic needs like cloth washing, domestic animal drinking and washing purpose.

\section{EXPERIMENTAL}

The study was conducted for a period of one year from Jan 2013 to Feb 2014. Dam water samples from Chilar Dam were collected in clear pre-sterilized polythene bottles. During field 


\section{INTERNATIONAL JOURNAL of RESEARCH -GRANTHAALAYAH

investigation physical parameter like $\mathrm{pH}$ and temperature were measured. Proper sampling and preservation techniques for collecting water samples for DO, COD etc. The physico-chemical parameters such as $\mathrm{pH}$, Conductivity, Alkalinity, Calcium, Magnesium, Chloride, Total Hardness, Fluoride, Nitrite, Do and COD were determined using standard method ${ }^{2-5}$. The method used for estimation of various nutrients and parameters are shown in Table-2. Reagent used for the present investigation was A.R. Grade and double distilled water was used for preparing various solutions. Methods used for estimation of various nutrients and parameters are shown in Table-2.

\section{Table 1:}

\begin{tabular}{|c|c|c|}
\hline S.No. & Sampling Point & Place \\
\hline 01 & S1E & East side of Chilar dam \\
\hline 02 & S2W & West side of Chilar dam \\
\hline 03 & S3N & North side of Chilar dam \\
\hline 04 & S4S & South side of Chilar dam \\
\hline & & \\
\hline
\end{tabular}

Table 2:

\begin{tabular}{|c|c|c|}
\hline S.No. & Parameters & Method \\
\hline 01 & $\mathrm{pH}$ & $\mathrm{pH}$ Metrically \\
\hline 02 & Conductivity $(\mu \mathrm{S})$ & Conductometrically \\
\hline 03 & Alkalinity $(\mathrm{mg} / \mathrm{l})$ & Titration Method \\
\hline 04 & Calcium & Titration Method \\
\hline 05 & Magnesium & EDTA Titration Method \\
\hline 06 & Chloride $(\mathrm{mg} / \mathrm{l})$ & Precipitation Titration \\
\hline 07 & Total Hardness $(\mathrm{ppm})$ & Titration Method \\
\hline 08 & Fluoride $(\mathrm{mg} / \mathrm{l})$ & Spectrophotometrically \\
\hline 09 & Nitrite $(\mathrm{ppm})$ & Spectrophotometrically \\
\hline 10 & Dissolved Oxygen & Winkler Method \\
\hline 11 & COD & Titration Method \\
\hline
\end{tabular}




\section{INTERNATIONAL JOURNAL of RESEARCH -GRANTHAALAYAH}

सुल्यालि: A knowledge Repository Science

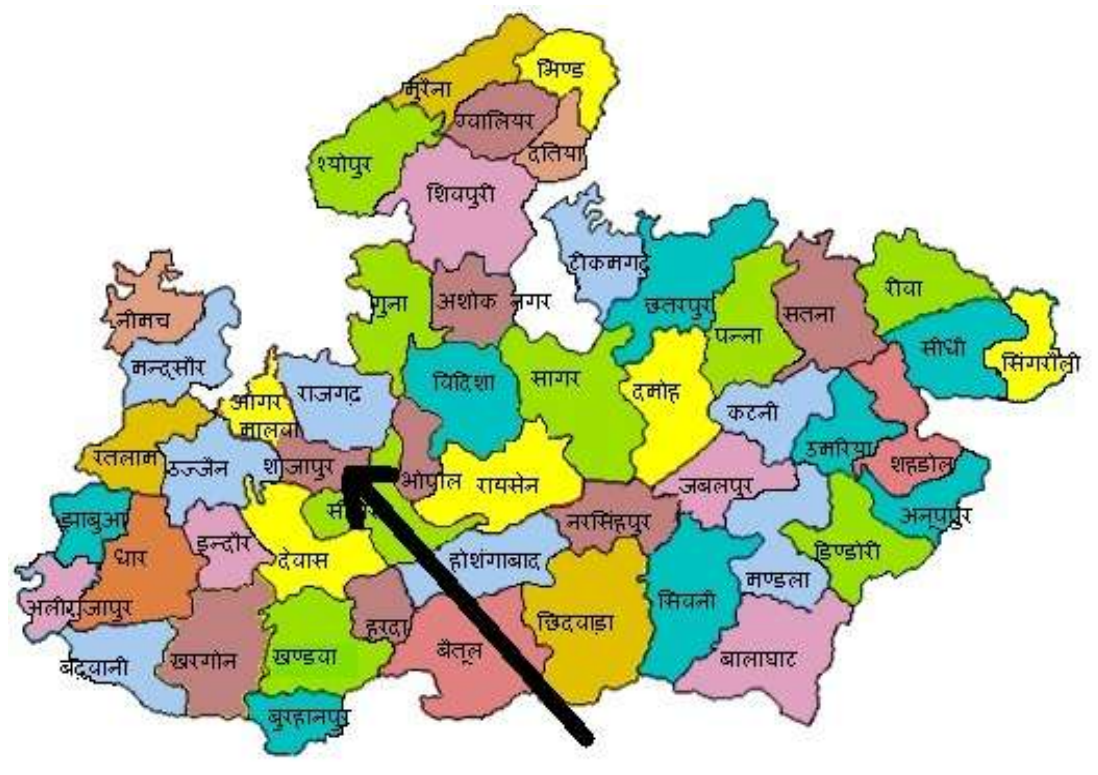

Figure 1: Madhya Pradesh Map

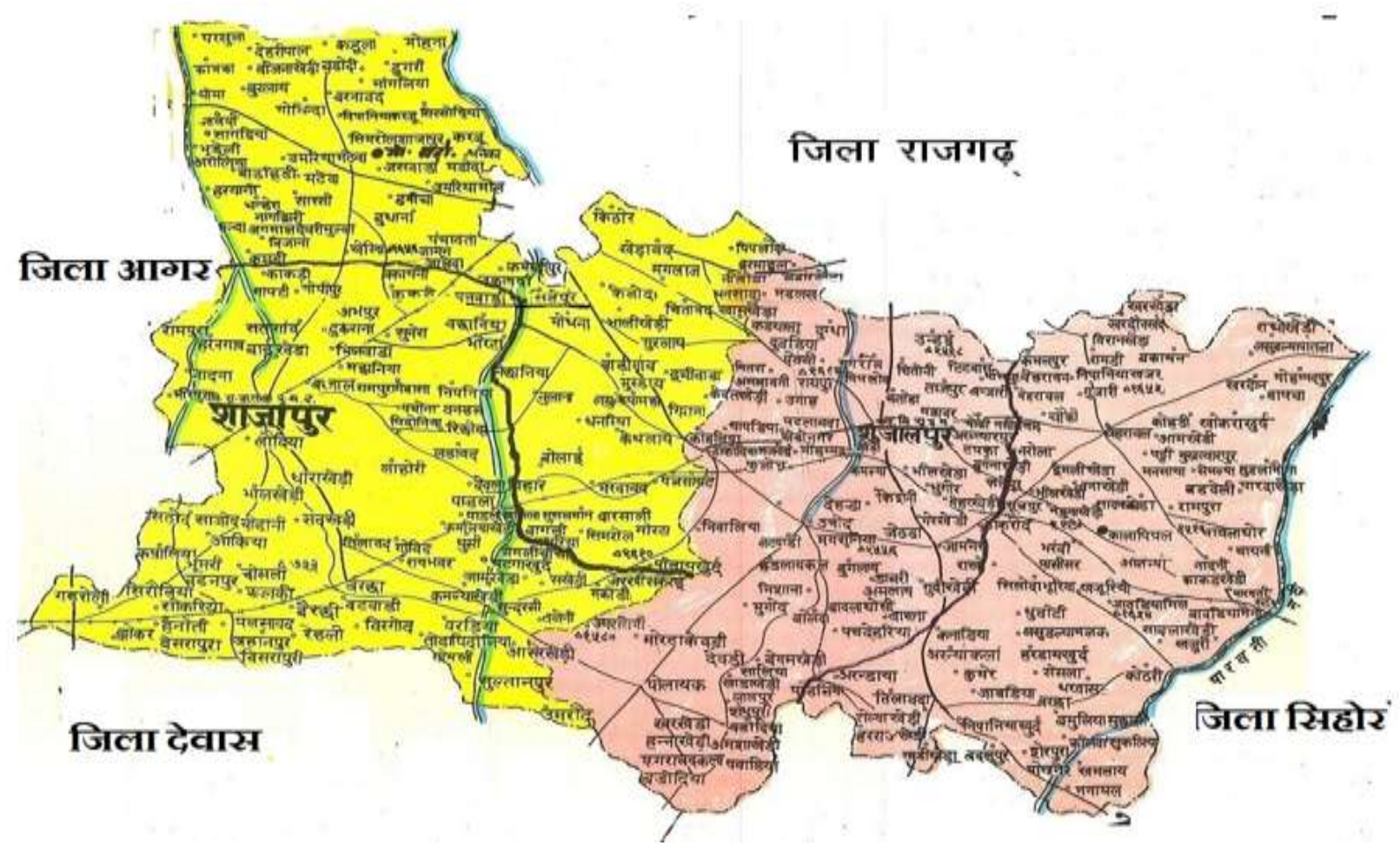

Figure 2: Shajapur Map 


\section{INTERNATIONAL JOURNAL of RESEARCH -GRANTHAALAYAH

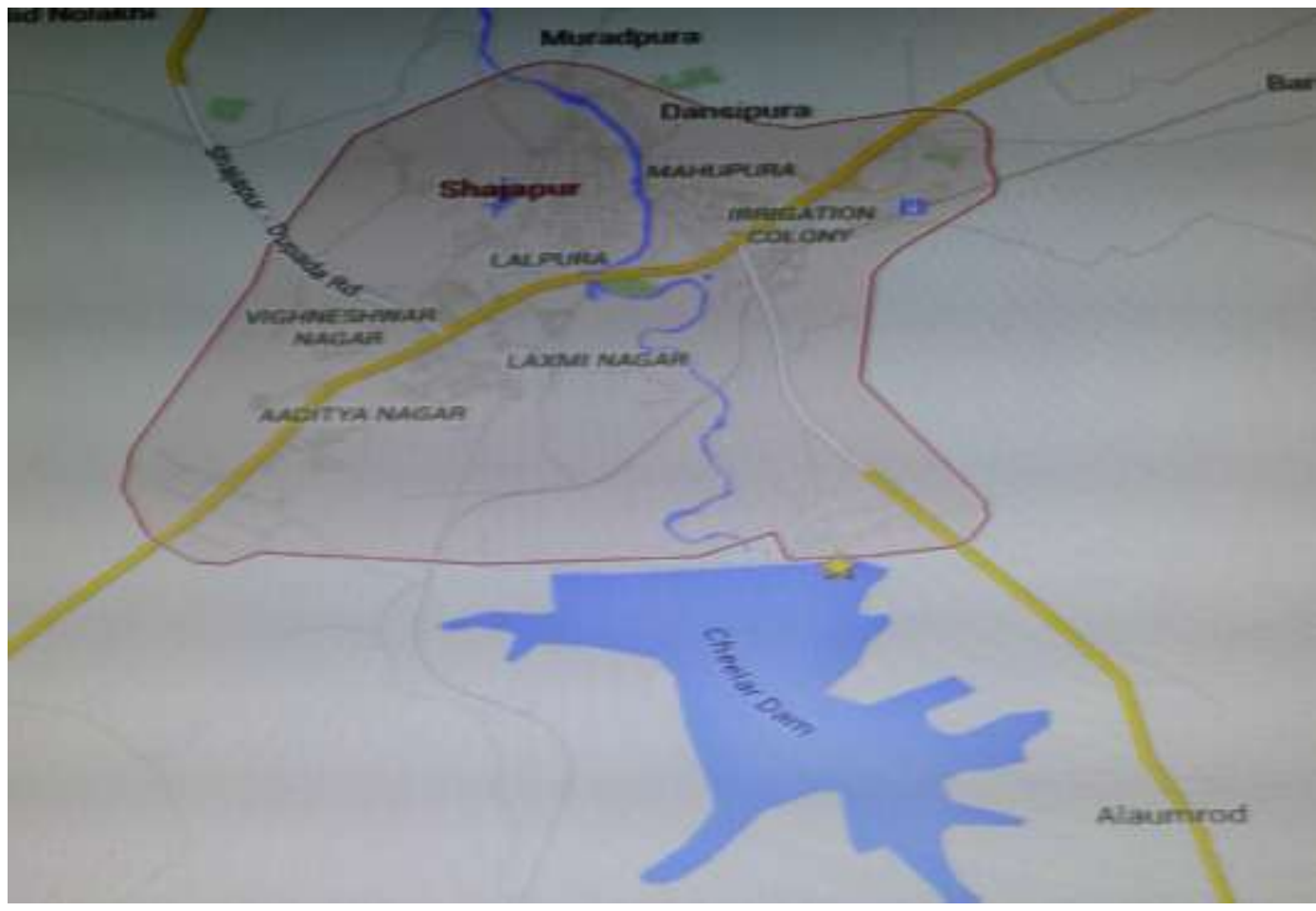

Figure 3: Shajapur and Chilar Dam on Google Map

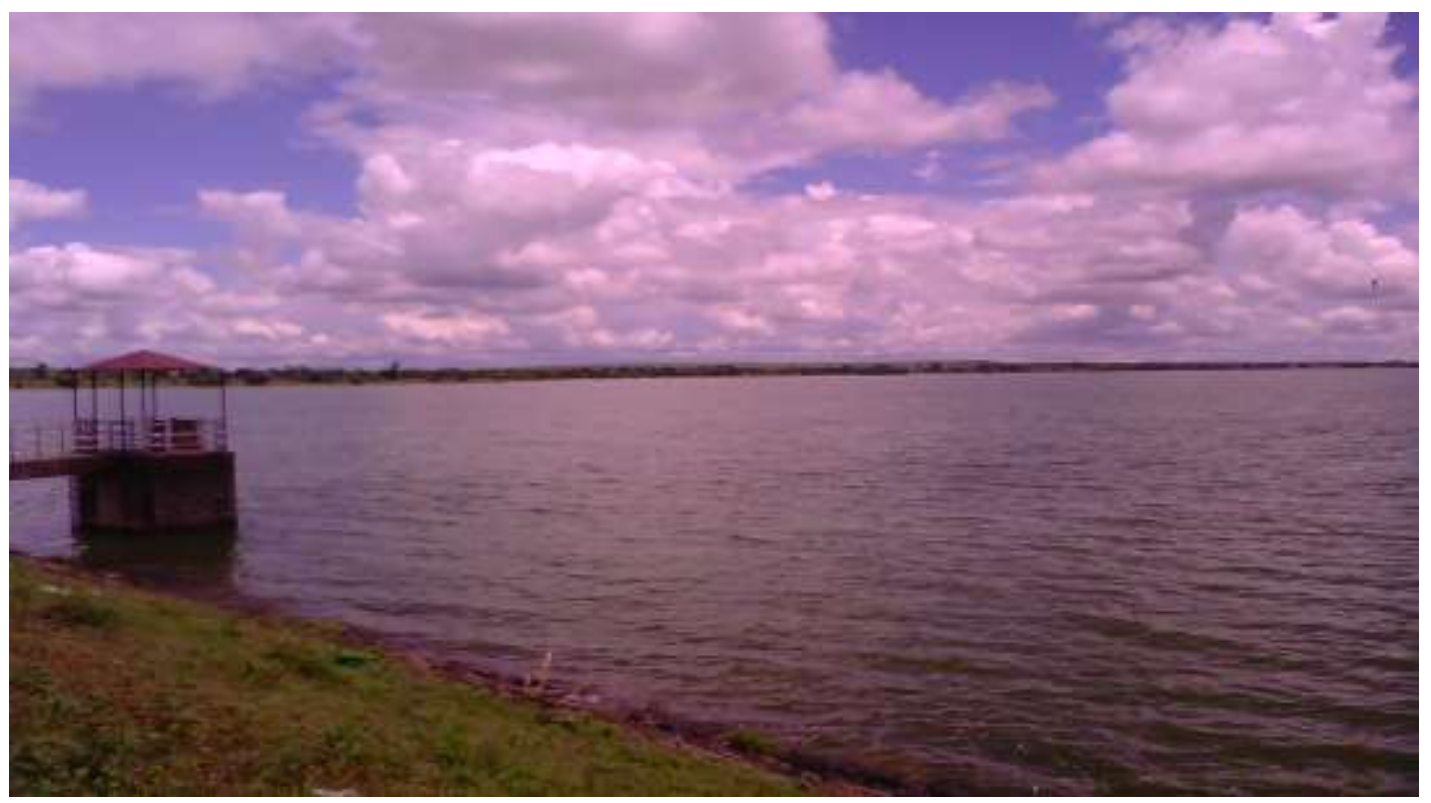

Figure 3: Real Photo of Chilar Dam 


\section{INTERNATIONAL JOURNAL of RESEARCH -GRANTHAALAYAH

\section{RESULTS AND DISCUSSION}

Physico-chemical parameters of water sample were determined in Jan 2013 to Feb 2014. The temperature of the sample was noted at the sample spot during collection. Other parameters like $\mathrm{pH}$, Conductivity, Alkalinity, Calcium, Magnesium, Chloride, Total Hardness, Fluoride, Nitrite, Do and COD were measured within few hours from sampling. The parameters were analyzed by prescribed standard method ${ }^{6}$. The variation in various parameters of different samples is shown in Table-3.

$p H$

The $\mathrm{pH}$ value of natural water changes due to biological activity and industrial contamination. $\mathrm{pH}$ has no adverse effects on health. The average $\mathrm{pH}$ values of this investigation are too low and well within the standard permissible limits ${ }^{7}$.

\section{CONDUCTIVITY}

Conductivity is Chilar Dam where it is $0.4 \times 10^{-3}$ to $0.6 \times 10^{-3}$

\section{ALKALINITY}

The main source for alkalinity is due to weathering of rocks. Higher alkalinity value contributes sour and saline taste to water. Although, alkalinity is not harmful to human beings yet the water supplied with less than $100 \mathrm{mg} / \mathrm{l}$ is desirable.

\section{CALCIUM}

The water above Calcium values $25 \mathrm{mg} / 1$ are classified as 'Calcium rich'. The present investigation shows that the concentration of calcium of the Chilar Dam water is 13 to $15 \mathrm{mg} / \mathrm{l}$.

\section{MAGNESIUM}

The observed value of Magnesium in dam water is maximum $4.46 \mathrm{mg} / \mathrm{l}$. The present investigations shows that the Magnesium content in majority of samples does not exceed the limit as prescribed by ISI as well as WHO.

\section{CHLORIDE}

The suitability of water resource for the irrigational use in agricultural is depends on its salt concentrations, especially Chloride contents. In the present investigation Chloride concentration is in the range of 37.70 to 40.60 in Dam water. 


\section{INTERNATIONAL JOURNAL of RESEARCH -GRANTHAALAYAH

\section{TOTAL HARDNESS}

Total hardness of water is caused by the presence of Calcium and, Magnesium salts. Hardness has no known adverse effect on health. However, maximum permissible level has been prescribed for drinking water is $500 \mathrm{mg} / \mathrm{l}$, by WHO. According some classifications water having Hardness up to $75 \mathrm{mg} / \mathrm{l}$ is classified as soft, 76 to $150 \mathrm{mg} / \mathrm{l}$ is moderately soft, $151-300 \mathrm{mg} / \mathrm{l}$ as hard and more $300 \mathrm{mg} / \mathrm{l}$ as very hard. In present investigation Hardness of samples of dam water is in the range of 111.05 to $117.90 \mathrm{mg} / \mathrm{l}$. the result shows that, this water is moderately soft ${ }^{8-10}$.

\section{FLUORIDE}

Fluoride is essential for human being as trace element and higher concentrations of this element causes toxic effects. The permissible limit of Fluoride for potable water is 0.6 to $1 \mathrm{mg} / \mathrm{l}$. in the present study concentration of fluoride varies in between 0.335 to $0.356 \mathrm{mg} / \mathrm{l}$ in dam water. Consumption of such water having fluoride more than $1.5 \mathrm{mg} / \mathrm{l}$ may cause degeneration of bones and dental mottling especially in pregnant women and children. It is suggested that defluoridation of the drinking water should be done at these stations.

\section{NITRITE}

Nitrate values are used to assess the self purification property of the water source. The main source of nitrate in water body is decaying plant and animal materials. The nitrate values of this investigation are well within the standard permissible limit ${ }^{7}$. The prescribed limit of NO3 - by WHO is $50 \mathrm{mg} / \mathrm{l}$ for domestic water. The concentration of different forms of Nitrogen gives a useful indications of the level of micronutrients in water and hence their ability to support for plant growth ${ }^{11-13}$.

\section{DISSOLVED OXYGEN}

During the study, the concentration of DO recorded is 2.09 to $2.13 \mathrm{mg} / \mathrm{l}$ for Chilar dam water.

$C O D$

C.O.D. is the major of oxygen consumed during the oxidation of oxydisable organic matter present in the water. C.O.D. of dam water is in the range 3.7 to $4.3 \mathrm{mg} / \mathrm{l} \mathrm{COD}$ of dam water is nearly same and below the permissible limit. 
Table 3:

\begin{tabular}{|c|c|c|c|c|c|}
\hline \multicolumn{2}{|c|}{ Sr.No. } & Parameters & \multicolumn{4}{c|}{ Chilar Dam } \\
\hline & & S1E & S2W & S3N & S4S \\
\hline 01 & $\mathrm{pH}$ & 7.20 & 7.25 & 7.19 & 7.17 \\
\hline 02 & Conductivity & $0.6 \times 10^{-3}$ & $0.5 \times 10^{-3}$ & $0.6 \times 10^{-3}$ & $0.4 \times 10^{-3}$ \\
\hline 03 & Alkalinity & 335 & 345 & 300 & 325 \\
\hline 04 & Calcium & 14.40 & 15.20 & 14.32 & 13.82 \\
\hline 05 & Magnesium & 4.46 & 4.01 & 4.22 & 3.30 \\
\hline 06 & Chloride & 37.70 & 40.60 & 38.92 & 39.47 \\
\hline 07 & Total Hardness & 111.05 & 117.90 & 114.75 & 115.89 \\
\hline 08 & Fluoride & 0.335 & 0.356 & 0.341 & 0.348 \\
\hline 09 & Nitrite & 0.00005 & 0.00007 & 0.00010 & 0.00012 \\
\hline 10 & Dissolved Oxygen & 2.11 & 2.10 & 2.09 & 2.13 \\
\hline 11 & COD & 4.2 & 4.3 & 3.9 & 3.7 \\
\hline
\end{tabular}

\section{CONCLUSION}

The results obtained from this study clearly indicate usability of Chilar dam water for drinking and other domestic purposes. It is also helpful for a common man to understand the drinking water quality.

\section{REFERENCES}

[1] S.K. Sharma et.al, " Ground water pollutions by domestic sewage and faecal matter discharged in to dry dug well in jarud area", proceeding of N.C on pollutions preventions and control in India, 2003, VRCE,Nagpur.

[2] K.V.J.R. Kripanidhi, "Mechanism of ground water pollution in village wells", Geological society of India, 1984, 25, 301.

[3] R.K. Trivedi and P.K. Goel, "Chemical and Biological methods for water pollution studies", Environment publication, Karad, 1984, 211-215.

[4] Madhu Rani Sinha et.al, J. Chem. Pharm. Res., 2011, 3(3), 701.

[5] B. Venkateswara Rao, International Journal of Environmental Sciences, 2011, 2(2), 710.

[6] Tailor Manthan A. and Mankodi Pradeep C., Int. Res. J. Environment Sci., 2013, 2(10), 58-62.

[7] Brown R.M., Mc Cleil, Deininger R.A. and O'Conner M.F., A water quality index crasing the psychological barrier, Edt. Bys. H. Jenkis, proc. Int. Conf. on water poll, Res. Jerusalem. 1972, 6,787-797.

[8] WHO, Wastes from Healthcare Activities, WHO information, act Sheet No., 2000, 253. 


\section{INTERNATIONAL JOURNAL of RESEARCH -GRANTHAALAYAH

[9] Horton R.K., An index number system for rating water quality, J. Water Poll. Cont. Fed., 1965, 3, 300-305.

[10] Srinivas J., Purushotham A.V. and Murali Krishna K.V.S.G., Determination of Water Quality Index in Industrial areas of Kakinada, Andhra Pradesh, INDIA, Int. Res. J. Environment Sci., 2013, 2(5), 37-45.

[11] APHA, Standard methods for the examination of water and waste water., 18th edt., WPCF Washington DC, 1989.

[12] Misra P.C. and Patel R.K., Quality of drinking water in Rourkela, outside steel town ship, J. Env. \& Poll., 2001, 8, 920, 165-169.

[13] Mohamed Hanipha M. and Zahir Hussain A., Study of Groundwater Quality at Dindigul Town, Tamilnadu, India, Int. Res. J. Environment Sci., 2013, 2(1), 68-73.

[14] Rao V., Narendra and Mahmood S.K., Nutrient status and biological characteristics of Hubsiguda pond, J. Env. Poll., 1995, 2(1), 31-34. 